\title{
Perawatan maloklusi Angle kelas II divisi 2 pasien dewasa dengan pencabutan dua premolar atas
}

\section{Tita Ratya Utari}

Program Studi Pendidikan Dokter Gigi, Fakultas Kedokteran dan Ilmu Kesehatan, Universitas Muhammadiyah Yogyakarta, Yogyakarta, Indonesia

Jl Lingkar Selatan, Tamantirto, Kasihan, Bantul, Yogyakarta, Indonesia; e-mail: tita_utari@yahoo.com

Submisi: 7 Juni 2016; Penerimaan: 27 Desember 2016; Publikasi online: 28 April 2017

\begin{abstract}
ABSTRAK
Maloklusi Angle kelas II divisi 2 dengan karakteristik retroklinasi insisivus sentral, proklinasi insisivus lateral disertai deep overbite yang parah menyebabkan gangguan estetik bagi pasien. pencabutan gigi premolar atas umumnya dilakukan untuk memperbaiki maloklusi pada pasien dewasa. Laporan kasus ini bertujuan memaparkan perawatan ortodontik dengan diagnosis maloklusi Angle Klas II Divisi 2 dengan tujuan memperbaiki crowding dan deep over bite sehingga diperoleh estetika yang baik. Kasus 1 , pasien perempuan berusia 19 tahun dengan overjet $0,5 \mathrm{~mm}$, deepbite (overbite $7,8 \mathrm{~mm}$ ), dan ANB $10^{\circ}\left(\mathrm{SNA} 92^{\circ}, \mathrm{SNB} 82^{\circ}\right)$. Kasus 2, pasien laki laki berusia 18 tahun dengan overjet $0,5 \mathrm{~mm}$, deepbite (overbite $9 \mathrm{~mm}$ ), dan ANB 10,5 (SNA 87, $5^{\circ}$, SNB $77^{\circ}$ ). Diagnosis kedua kasus tersebut maloklusi Angle kelas II divisi 2 dengan insisivus sentralis rahang atas palatoversi, insisivus lateralis labio versi disertai crowding gigi anterior dan bentuk lengkung trapezoid. Pasien dilakukan perawatan ortodontik menggunakan alat cekat Straight Wire System dengan pencabutan premolar pertama kanan dan kiri rahang atas. Perawatan diawali dengan melakukan koreksi inklinasi gigi insisivus sentral atas sehingga memungkinkan pemasangan braket pada rahang bawah. Dilanjutkan distalisasi gigi kaninus, kemudian retraksi sekaligus intrusi gigi anterior rahang atas menggunakan wire dengan U-loop. Perawatan klas II divisi 2 dengan pencabutan premolar pertama rahang atas kanan dan kiri dapat memperbaiki relasi gigi anterior. Deep overbite dan crowding gigi anterior pada kedua pasien tersebut dapat dikoreksi sehingga diperoleh estetika wajah yang jauh lebih baik.
\end{abstract}

Kata kunci: maloklusi; klas II divisi 2; pencabutan premolar; straight wire system

\begin{abstract}
Treatment of maloclussion angle class II division 2 in adult patient with two maxillary premolar extractions. Angle Malocclusion class II division 2 had a characteristic of central incisor retroclination, lateral incisor proclination, added by severe deep overbite that caused aesthetic disturbance to the patient. In adult patient this type of case usually is treated with first premolar extraction. This case report aimed to describe orthodontic treatment in maloclussion Angle class II division 2 to correct anterior crowding deep overbite which finally improve the aesthetics. A

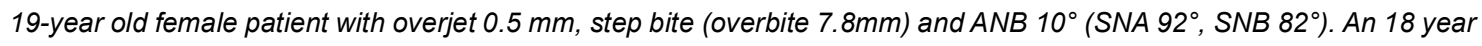
old male patient with overjet $0.5 \mathrm{~mm}$ step bite (overbite $9 \mathrm{~mm}$ ) and $A N B 10,5^{\circ}\left(\mathrm{SNA} 87,5^{\circ}\right.$, SNB $\left.77^{\circ}\right)$. Both patients were diagnosed with malocclusion Angle class II division 2 with the palatoversi of central incisor, labioversi of lateral incisor and anterior crowding with trapezoid shape of the jaw. Patient was given orthodontic treatment using fixed appliance with straight wire system and extraction of upper first premolar. The treatments began by correcting the inclination of central incisor that allowed braces installation in lower anterior teeth. Canine was distalized then anterior retraction, it followed by intrusion of anterior maxilla using U loop. Treatment for malocclusion Angle Class II division 2 with the extraction of upper first premolar feasible for correcting its anterior relation. Deep overbite and anterior crowding in both patients were corrected for better face aesthetics.
\end{abstract}

Keywords: malocclusion; class II division 2; premolar extraction; straight wire system

\section{PENDAHULUAN}

Karakteristik maloklusi kelas II divisi 2 sering kali disertai dengan deepbite yang parah, insisivus sentral maksila dan mandibula inklinasi kearah lingual, dan insisivus lateral maksila inklinasi ke arah labial. ${ }^{1}$ Maloklusi ini diakui memiliki kombinasi yang unik dari overbite, gigi seri retroklinasi, dan adanya perbedaan sagital. Fenotipe kelas II divisi 2 yang sangat parah, ditandai dengan penutupan gigi seri rahang bawah pada saat oklusi, dalam bahasa Jerman disebut 'Deckbiss' yang artinya menutupgigitan ('cover-bite'). Cover-bite atau Deckbiss didefinisikan sebagai ekspresi yang parah dari maloklusi Angle kelas II divisi 2, ditandai penutupan 
penuh mahkota gigi insisivus rahang bawah karena overbite berlebihan dan retroklinasi dari gigi seri rahang atas. ${ }^{2}$ Von-Der-Linden mengklasifikasikan maloklusi Angle kelas II divisi 2 menjadi 3 berdasarkan tingkat keparahan relasi insisivus yaitu: (1) tipe A dimana insisivus sentral rahang atas dan lateral retroklinasi namun tingkat retroklinasi tidak terlalu parah, (2) tipe B dimana gigi insisivus lateral rahang atas tumpang tindih (overlapping) dan gigi insisivus sentral atas retroklinasi, (3) tipe C dimana insisivus sentral dan lateral rahang atas yang retroklinasi dan tumpang tindih (overlapping) dengan gigi taring rahang atas. ${ }^{3}$

Maloklusi Angle kelas II divisi 2 merupakan kasus yang relatif jarang terjadi dibandingkan dengan maloklusi yang lain dengan frekuensi $1,5 \%-5 \%$ dari seluruh maloklusi yang ditemukan di populasi Caucasoid. ${ }^{4}$ Penelitian di New York, Amerika Serikat diperoleh 23,8\% mempunyai maloklusi Klas II. ${ }^{5}$ Maloklusi Angle Klas I merupakan maloklusi yang cenderung lebih umum terjadi daripada Kelas II, dimana maloklusi Angle Kelas II divisi 1 terjadi lebih sering daripada divisi 2, namun prevalensi kelas II masih lebih tinggi dari Angle kelas III. ${ }^{6}$ Walaupun jarang terjadi, kasus ini menyebabkan gangguan oklusi maupun estetik bagi pasien sehingga membutuhkan perawatan.

Maloklusi kelas II divisi 2 muncul dari sejumlah faktor yang saling berkaitan yaitu dental, skeletal, jaringan lunak dan faktor genetik. Sebagian besar maloklusi kelas II divisi 2 disebabkan oleh skeletal diskrepansi, dan beberapa memiliki hubungan skeletal yang normal. ${ }^{3}$ Pola skeletal pada maloklusi kelas II divisi 2 biasanya kelas II ringan atau kelas I dan meskipun sangat jarang bisa juga pola skeletal kelas III ringan. Tinggi muka yang berkurang disertai relasi skeletal kelas II sering menyebabkan tidak adanya stop antara insisivus bawah dengan insisivus atas sehingga insisivus bawah bererupsi melebihi normal sehingga terjadi gigitan dalam. Pengaruh bibir bawah sangat besar terutama bila didapatkan high lower lip line (bibir bawah menutupi lebih dari sepertiga panjang mahkota insisivus) yang menyebabkan posisi insisivus atas retroklinasi. ${ }^{7}$

Pasien-pasien maloklusi kelas II divisi 2 cenderung menunjukkan masalah dengan oklusal plane atas dan bawah, seperti kurva spee yang dalam. Jaringan lunak pada bibir sering kali selaras menyesuaikan dengan maloklusi, sehingga bibir menjadi berlebih dengan adanya sulkus mentolabial yang dalam. Karena deepbite dan supra erupsi dari gigi insisivus rahang atas, margin gingiva gigi anterior rahang atas biasanya malaligned, dan gigi insisivus rahang bawah yang inklinasinya kearah lingual cenderung memiliki margin gingiva lebih tinggi. Protokol perawatan untuk pasien ini meliputi ekstraksi premolar untuk memperbaiki crowding, dengan secara simultan mengkoreksi gigitan dalam dengan cara intrusi gigi insisivus atas dan/atau gigi insisivus bawah. ${ }^{1}$ Pasien yang masih dalam masa pertumbuhan dapat dilakukan perawatan dua tahap berupa modifikasi pertumbuhan dan perawatan ortodontik, sedangkan pada pasien dewasa dilakukan perawatan kompromi. ${ }^{8}$

Laporan kasus ini bertujuan menggambarkan perawatan ortodontik pada maloklusi Angle Klas II Divisi 2 dengan rencana perawatan memperbaiki crowding pada kedua lengkung rahang, memperbaiki inklinasi insisif sentral rahang atas yang retrusif, dan insisivus lateral yang labioversi serta memperbaiki overbite yang dalam dengan pencabutan gigi premolar pertama karena pasien sudah dewasa. Pasien telah menyetujui untuk dipublikasikan kasusnya bagi kepentingan ilmu pengetahuan.

\section{METODE}

Studi kasus dilakukan pada dua kasus, pada kasus 1, pasien perempuan berusia 19 tahun yang mengeluhkan gigi depan yang tidak teratur, gigi seri atas tampak lebih lingual dan menutup gigi depan bawah sehingga kurang percaya diri untuk tersenyum. Pasien memiliki riwayat kesehatan umum yang baik (Gambar 1). Kasus 2 adalah pasien laki laki berusia 18 tahun yang mengeluhkan gigi depan yang tidak teratur, gigi seri atas tampak lebih lingual dan menutup gigi depan bawah sehingga kurang percaya diri untuk tersenyum. Pasien memiliki riwayat kesehatan umum yang baik. Diagnosis dan etiologi pasien kasus 1, pada pemeriksaan ekstra oral (Gambar 1) tampak wajah normal simetri, profil datar (lurus), relasi bibir normal, dan tidak ditemukan kelainan TMJ. 

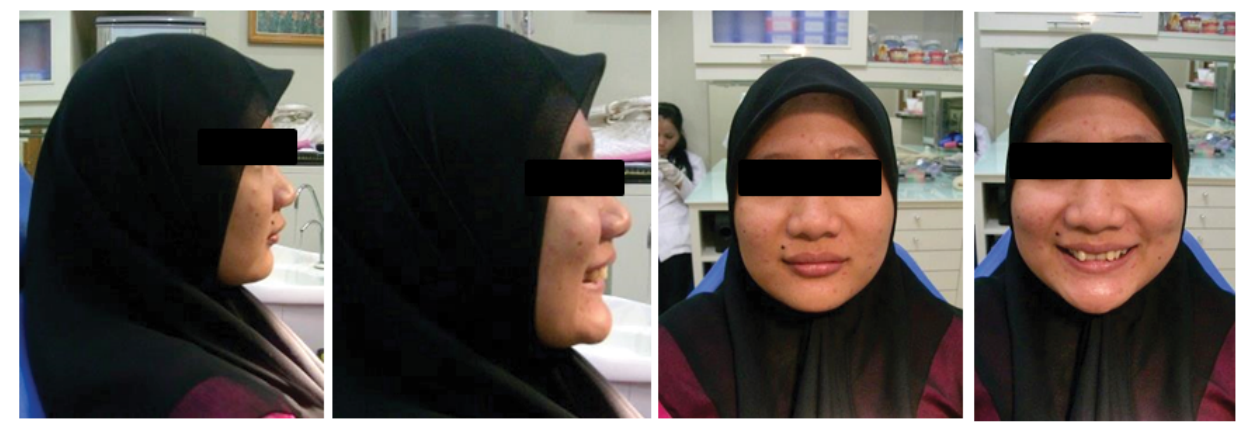

Gambar 1. Kasus 1. Foto ekstra oral pasien sebelum perawatan
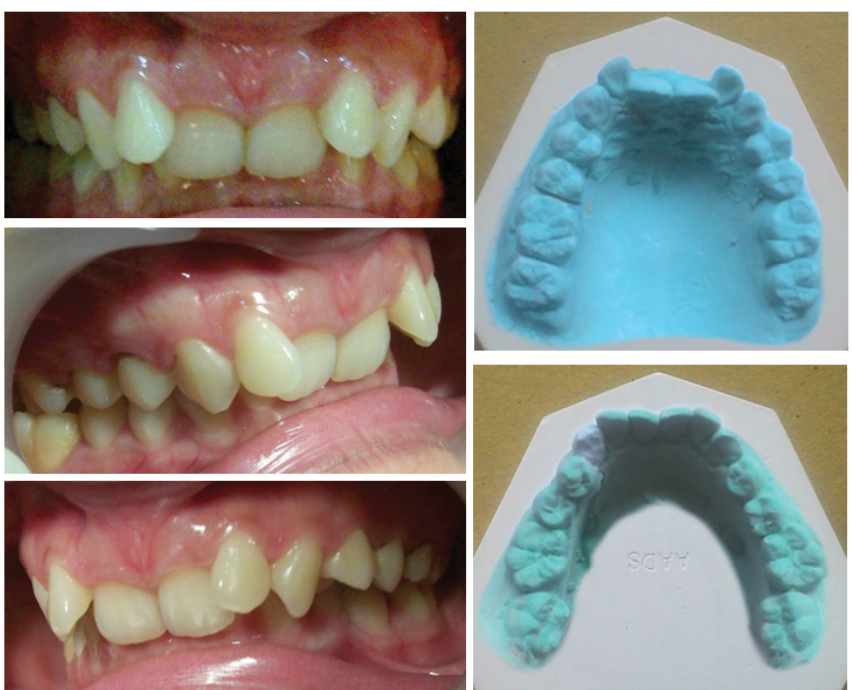

Gambar 2. Kasus 1. Foto intra oral pasien sebelum perawatan

Pada pemeriksaan intra oral (Gambar 2) tampak crowding berat pada rahang atas dan crowding sedang pada rahang bawah, gigitan dalam, overjet kecil, deepbite, retroklinasi 11,21, proklinasi 12,22, crossbite gigi 16 dan 17 terhadap gigi 46 dan 47, scissor bite gigi 24 dan 25 terhadap gigi 34 dan 35 . Analisa model terlihat hubungan molar dan kaninus kanan dan kiri kelas II. Overbite sebesar 7,8 $\mathrm{mm}$ dimana seluruh gigi anterior bawah tertutup oleh gigi anterior rahang atas dan overjet $0,5 \mathrm{~mm}$. Bentuk lengkung trapezoid. Analisis model menunjukkan kekurangan ruangan sebesar $6,5 \mathrm{~mm}$ pada rahang atas kanan dan $5,5 \mathrm{~mm}$ pada rahang atas kiri.

Pemeriksaan panoramik (OPG) sebelum perawatan (Gambar 3) menunjukkan semua gigi permanen telah erupsi kecuali molar ketiga belum erupsi. Tidak terdapat kelainan periapikal yang menunjukkan semua gigi dalam kondisi sehat. Analisis sefalogram lateral sebelum perawatan menunjukkan pola skeletal kelas II dengan sudut SNA $92^{\circ}$ (prognati maksila), sudut SNB $82^{\circ}$, sudut ANB $10^{\circ}$ (kelas II). Berdasarkan hasil pemeriksaan ekstra oral, intra oral, analisis model dan analisis sefalometri, diperoleh diagnosis maloklusi Angle kelas II divisi 2 dentoskeletal disertai crowding anterior dan gigitan dalam anterior (step bite).

Pada pemeriksaan ekstra oral kasus 2 (Gambar 4) tampak wajah asimetri, profil datar (lurus), relasi bibir normal, dan tidak ditemukan kelainan TMJ. Pada pemeriksaan intra oral (Gambar 5) tampak crowding berat pada rahang atas dan rahang bawah, gigitan dalam, overjet kecil, deepbite, retroklinasi $11,21,12$, proklinasi 13,22 , crossbite gigi 17 terhadap gigi 48 , cups to cups gigi 25 terhadap gigi 34 dan 35 . 

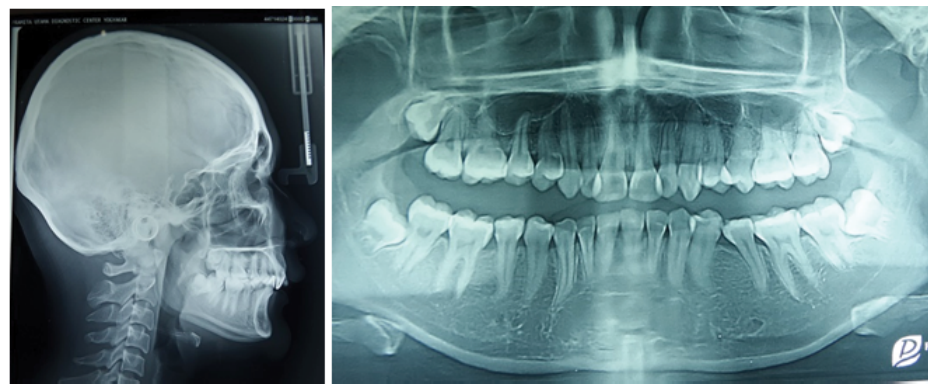

Gambar 3. Kasus 1. Foto sefalometri dan panoramix sebelum perawatan
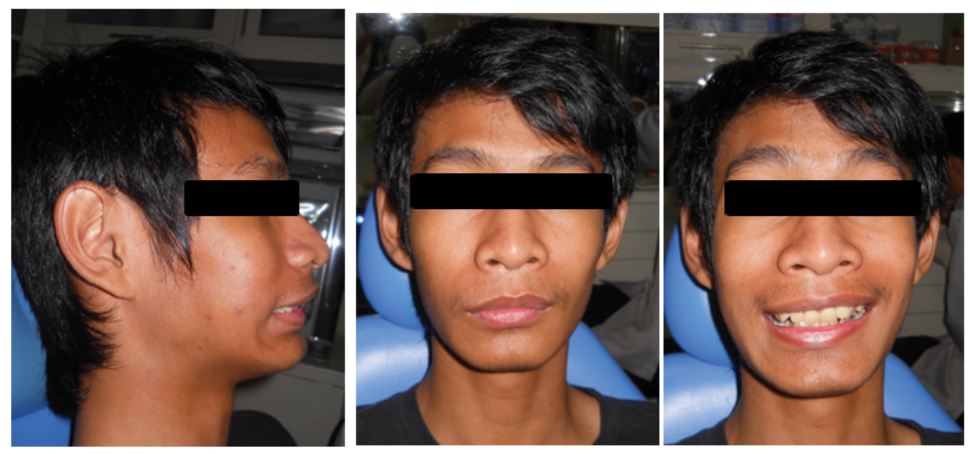

Gambar 4.Kasus 2. Foto ekstra oral pasien sebelum perawatan
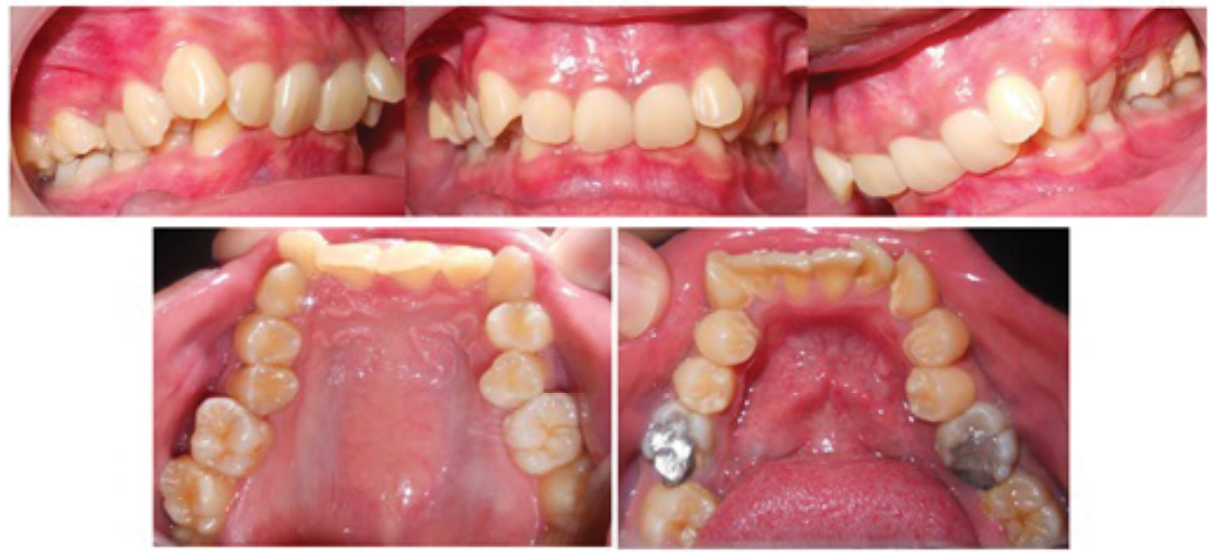

Gambar 5. Kasus 2. Foto intra oral pasien sebelum perawatan
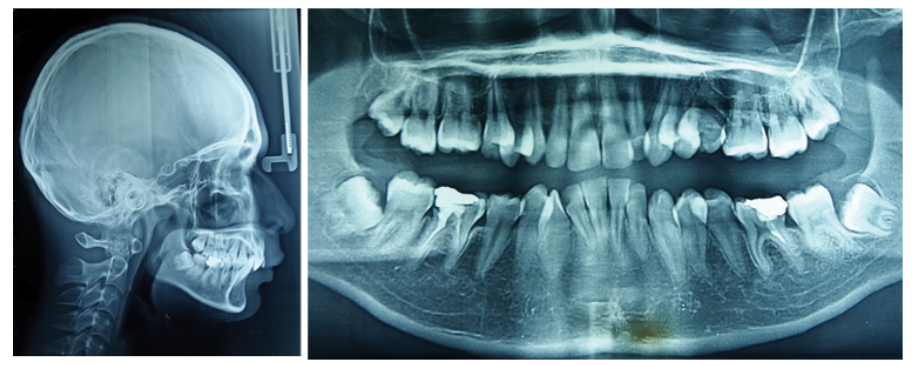

Gambar 6. Kasus 2. Foto sefalometri dan panoramix sebelum perawatan

Analisa model terlihat hubungan molar dan kaninus baik kanan maupun kiri kelas II. Overbite sebesar $9 \mathrm{~mm}$ dimana seluruh gigi anterior bawah tertutup oleh gigi anterior rahang atas dan overjet $0,5 \mathrm{~mm}$. Bentuk lengkung trapezoid. Analisis model menunjukkan kekurangan ruangan sebesar $6 \mathrm{~mm}$ 
pada rahang atas kanan dan $7 \mathrm{~mm}$ pada rahang atas kiri. Pada rahang bawah kekurangan ruangan sebesar $4 \mathrm{~mm}$ pada sisi kanan dan $4,5 \mathrm{~mm}$ sisi kiri

Pemeriksaan panoramik (OPG) sebelum perawatan (Gambar 6) menunjukkan semua gigi permanen telah erupsi kecuali molar ketiga belum erupsi. Terdapat kelainan periapikal pada gigi 36 dan 46 dimana gigi tersebut pernah dilakukan perawatan saluran akar yang kurang sempurna. Analisis sefalogram lateral sebelum perawatan menunjukkan pola skeletal kelas II dengan sudut SNA $87,5^{\circ}$ (prognati maksila), sudut SNB $77^{\circ}$, sudut ANB $10,5^{\circ}$ (kelas II). Berdasarkan hasil pemeriksaan ekstra oral, intra oral, analisis model dan analisis sefalometri, diperoleh diagnosis maloklusi Angle kelas II divisi 2 dentoskeletal disertai crowding anterior dan gigitan dalam anterior (step bite).

\section{HASIL}

Prosedur perawatan yang dilakukan pada kedua pasien tersebut hampir sama yaitu dengan menggunakan alat cekat Straight Wire System slot.022 dengan buccal tube sampai pada molar kedua rahang atas. Dimulai dengan tahap leveling dan alignment menggunakan kawat Niti 0,012 inch untuk melakukan flaring pada gigi anterior rahang atas. Pemasangan braket pada rahang bawah belum dilakukan karena gigitan dalam yang tidak memungkinkan untuk penempatan braket. Setelah kurang lebih 4 bulan posisi insisivus rahang atas yang retrusif telah mengalami flarring sehingga terdapat jarak antara rahang atas dan rahang bawah (overjet meningkat). Selanjutnya dilakukan pemasangan bracket pada rahang bawah, dilakukan leveling dan alignment awal dengan kawat Niti 0.012 . Pada rahang atas kawat diganti dengan Niti 0.016 dan tahap leveling dan alignment masih dilanjutkan.

Tahap selanjutnya dilakukan pencabutan untuk mengatasi kekurangan ruang. Pada kasus ke-1 dilakukan pencabutan pada gigi 14 dan 24. Pada kasus ke-2 dilakukan pencabutan pada gigi 14, 24. Gigi 36 dan 46 dicabut karena sudah gangren, pernah dilakukan perawatan saluran akar namun kurang baik dan sudah sering abses. Pencabutan 36 dan 46 pada kasus ke-2 ini digunakan untuk mengatasi kekurangan ruang pada rahang bawah dan diharapkan dapat memberi ruang erupsi gigi 38 dan 48. Tahap levelling dan alignment tetap dilanjutkan menggunakan Niti 0,018, Niti 0,016 x 0.022 dan kawat SS rectangular $0,016 \times 0,022$ inch. Pada tahap ini deep overbite mulai terkoreksi.

Tahap selanjutnya adalah retraksi kaninus menggunakan power chain dilanjutkan dengan retraksi gigi anterior rahang atas menggunakan kawat rectangular 0,016 x 0,016 inch dengan U-loop di antara gigi 13, 12 dan 23, 22. Loop sisi mesial lebih tinggi daripada sisi distal untuk memberikan efek intrusi gigi insisivus atas.

Setelah kurang lebih 18 bulan perawatan, insisivus sentral yang retrusif, crowding rahang atas dan rahang bawah dan deep overbite telah terkoreksi. Relasi kaninus dapat tercapai kelas I namun hubungan molar tetap klas II. Overjet dan overbite normal, lengkung rahang atas dan bawah simetris dan berbentuk parabola (Gambar 7 dan 8).

Pada pasien ke-2, perawatan masih dilakukan untuk penutupan sisa ruang (space closing) dan koreksi interdigitasi gigi posterior. Kasus ini masih membutuhkan waktu yang cukup lama, karena penutupan sisa ruang dilakukan mesialisasi gigi 37 dan 47 sehingga memberi ruang erupsi gigi 38 dan 48. Sampai saat ini pasien masih dilakukan perawatan menggunakan elastik intermaksiler kelas II.

\section{PEMBAHASAN}

Maloklusi Angle Kelas II divisi 2 yang ditandai dengan retroklinasi dari insisivus sentral biasanya berhubungan dengan deep overbite yang tampak jelas. Para ahli sering mengandalkan ekstraksi gigi premolar atas untuk memperbaiki anomali ini pada pasien dewasa. Prosedur ini memerlukan kontrol penjangkar yang memadai untuk memastikan hubungan yang tepat pada relasi gigi kaninus. ${ }^{9}$ Kedua kasus ini terjadi pada pasien dewasa dan sudah melewati masa pertumbuhan sehingga perawatan dilakukan dengan pencabutan gigi premolar atas. Pemasangan buccal tube sampai pada molar kedua rahang atas untuk menambah anchorage. Ruang pencabutan gigi premolar tersebut mencukupi untuk koreksi crowding gigi anterior, perbaikan bentuk lengkung, dan distalisasi kaninus sehingga tercapai relasi kaninus kelas I. 
Majalah Kedokteran Gigi Indonesia. April 2017; 3(1): 51 - 58

ISSN 2460-0164 (print)

ISSN 2442-2576 (online)
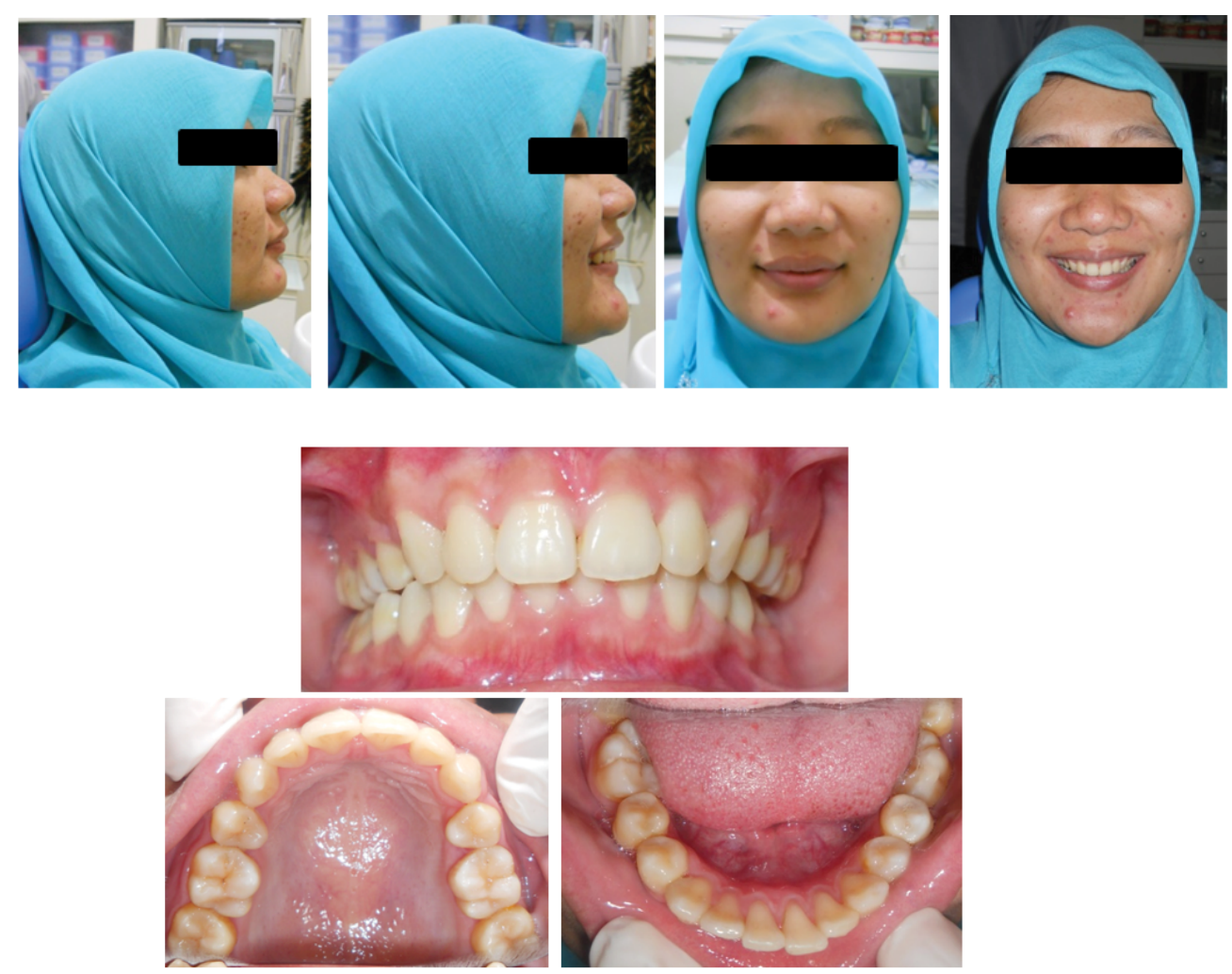

Gambar 7. Kasus 1: Foto ekstra oral dan intra oral pasien setelah perawatan
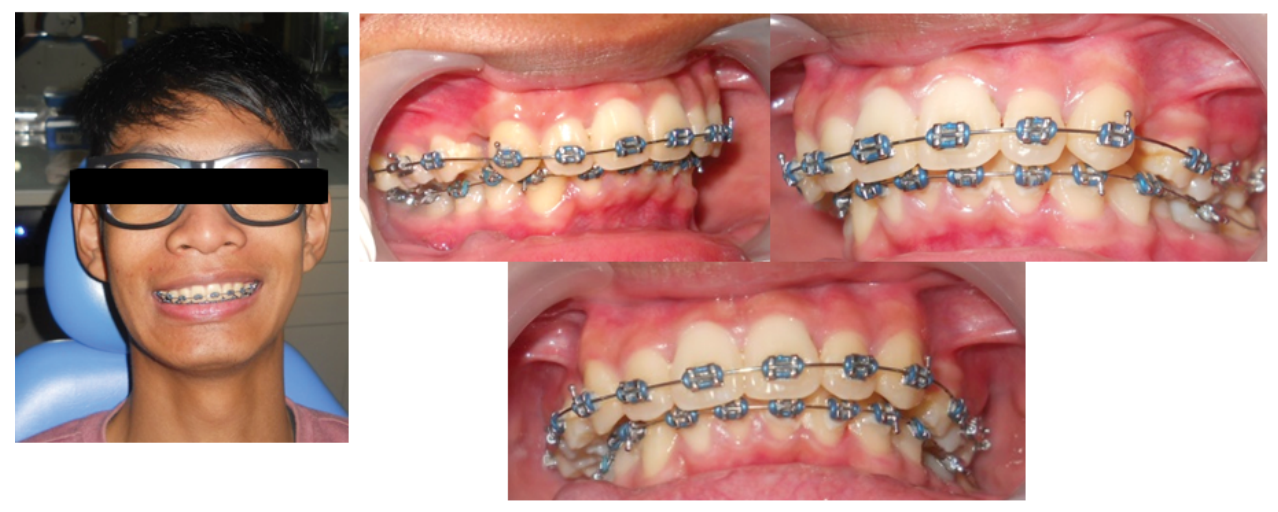

Gambar 8. Kasus 2: Foto intra oral pasien setelah 18 bulan perawatan

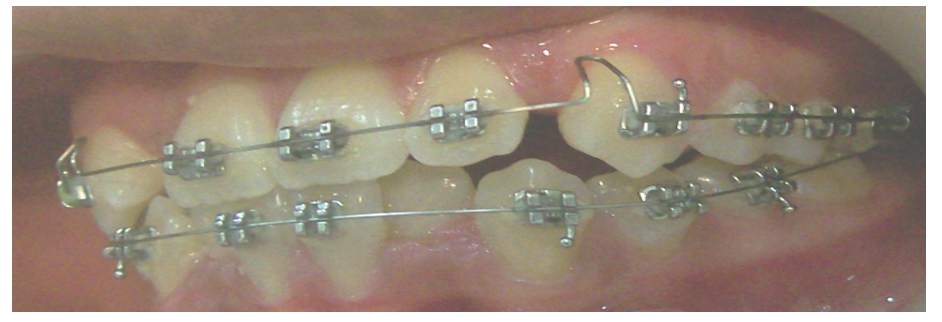

Gambar 9. U-loop sisi mesial lebih tinggi dari sisi distal 
Tiga strategi perawatan ortodontik mendasar untuk koreksi gigitan dalam (tidak termasuk opsi bedah) adalah: ekstrusi gigi posterior; flaring gigi anterior; dan intrusi gigi insisivus atas dan/atau gigi insisivus bawah. Efek ini paling sering dapat dicapai melalui biomekanik penggunaan bite plate, reverse curve arch wires, penggunaan step bends pada arch wire, dan kawat intrusi. Intrusi gigi insisivus atas dan/atau insisivus bawah merupakan salah satu metode yang diperlukan untuk memperbaiki gigitan dalam pada banyak pasien remaja dan dewasa. Koreksi optimal gigitan yang dalam membutuhkan diagnosis yang tepat, perencanaan perawatan individual, dan penentuan mekanik perawatan yang efisien. ${ }^{10}$ Perawatan ortodontik dengan alat cekat efektif dalam perawatan maloklusi Angle kelas II, bahkan pada pasien dewasa. ${ }^{11}$ Pada pasien dewasa, rencana perawatan Kelas II divisi 2 sering kali dilakukan ekstraksi gigi premolar pertama rahang atas untuk memfasilitasi penjangkaran dan mengurangi waktu perawatan. ${ }^{12}$

Pada kedua kasus ini, setelah leveling dan alignment tercapai dan distalisasi kaninus atas telah berhimpit dengan premolar kedua, retraksi gigi insisivus dilakukan menggunakan kawat intrusi. Kawat pada rahang atas dibuat U-loop di antara gigi 13, 12 dan 23, 22. Kaki U-loop sisi mesial lebih tinggi daripada sisi distal untuk memberikan efek intrusi gigi insisivus atas (Gambar 9). Ligasi pada gigi 17, 16, 15, 13 dan 27, 26, 25, 23 kemudian retraksi dilakukan menggunakan power chain dari gigi 13 ke 23 sehingga terjadi efek retraksi sekaligus instrusi.

Hasil perawatan pada kedua kasus ini tidak dapat mengkoreksi relasi molar kelas II namun dapat diperoleh relasi kaninus kelas I dengan interdigitasi yang baik. Crowding, gigitan yang dalam, overbite, overjet, crossbite serta bentuk lengkung yang baik dapat dicapai sehingga pasien mendapatkan senyum dan estetika wajah yang jauh lebih baik.

Tujuan perawatan pada maloklusi angle kelas II divisi 2 meliputi menghilangkan trauma di gingiva, koreksi hubungan insisivus, mengurangi crowding dan penyimpangan lokal, koreksi hubungan segmen bukal. Peran ekstraksi dalam perawatan dan koreksi hubungan segmen bukal pada dasarnya sama seperti yang dijelaskan untuk kelas II divisi 1 maloklusi. Overbite anterior yang dalam dan retroklinasi yang merupakan karakteristik dari divisi 2 maloklusi dapat di rawat dengan cara pengurangan overbite insisal dan mengubah inklinasi insisal. ${ }^{13}$ Hasil perawatan pada kasus ini sudah tercapai tujuan yaitu terkoreksinya crowding, relasi insisivus yang normal baik over jet maupun overbite sehingga dapat mengatasi adanya trauma gingiva.

\section{KESIMPULAN}

Perawatan maloklusi klas II divisi 2 dengan pencabutan premolar pertama atas pada kasus ini dengan menggunakan braket sistem Stright Wire pada pasien dewasa memperlihatkan hasil yang baik. Penggunaan $U$-loop dengan sisi mesial lebih tinggi daripada sisi distal efektif memberikan efek intrusi pada gigi insisivus atas sehingga gigitan dalam (cover-bite) pada kedua kasus ini dapat terkoreksi.

\section{DAFTAR PUSTAKA}

1. Uribe F, Nanda R. Treatment of class II, division 2 malocclusion in adults: biomechanical considerations. J Clin Orthod. 2003; 37(11): $599-606$.

2. Peck S, Peck L, Kataja M. Class II division 2 malocclusion: a heritable pattern of small teeth in well-developed jaws. Angle Orthod. 1998; 68(1): 9 - 20.

3. BAU-Department of Orthodontics. Class II division 2 malocclusion [Internet]. Health \& Medicine presented at; 17:46:12 UTC [cited 2016 Jan 28]. Available from: http:// www.slideshare.net/zeinaabouzour/class-iidivision-2-malocclusion-35405680

4. Brezniak N, Arad A, Heller M, Dinbar A, Dinte A, Wasserstein A. Pathognomonic cephalometric characteristics of Angle class II division 2 malocclusion. Angle Orthod. 2002; 72(3): $251-257$. 
5. Proffit W, Fields H. Contemporary orthodontics. 2nd ed. St. Louis: Mosby; 1993. 4.

6. Sridharan K, Udupa V, Srinivas H, Kumar $\mathrm{S}$, Sandbhor S. Prevalence of Class II Malocclusion in Tumkur Population. J Dent Sci Res. 2011; 2(2): 1 - 5.

7. Mitchell L. An Introduction to orthodontics. Oxford University Press; 2007. 111 - 119.

8. Nanda R, Kapila S. Current therapy in orthodontics. St. Louis, Missouri: Mosby Elsevier; 2010. 115 - 116.

9. Ribeiro P. Division 2, Malocclusion with deep overbite. Dental Press J Orthod. 2010; 15(1): $132-143$.
10. Nanda R. The differential diagnosis and treatment of excessive overbite. Dent Clin North Am. 1981; 25(1): 69 - 84.

11. Basavaraddi S, Gandedkar NH, Belludi A, Patil A. Correction of an adult class II division 2 individual using fixed functional appliance: a noncompliance approach. Contemp Clin Dent. 2016; 7(1): $82-86$.

12. Dalagnol SL. Angle Class II, Division 2 malocclusion treated with extraction of permanent teeth. Dental Press J Orthod. 2011; 16(3): 125 - 135.

13. Bhalajhi SI. Orthodontics the art and science. New Delhi: Arya (med) Publishing House; 2004. 405 - 406. 